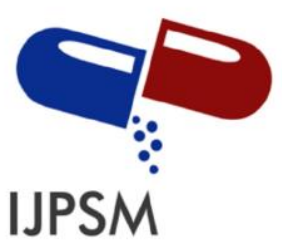

Ali Sandi Dwi Cahyo et al, Int. Journal of Pharmaceutical Sciences and Medicine (IJPSM), Vol.6 Issue. 9, September- 2021, pg. 8-16

\title{
Anti-Inflammatory and Analgesic Potential of Chromolaena odorata: A Review
}

\author{
Ali Sandi Dwi Cahyo ${ }^{1}$; Sri Oktavia ${ }^{1}$; Ifora Ifora ${ }^{1^{*}}$ \\ ${ }^{1}$ Department of Pharmacology and Clinical Pharmacy, School of Pharmaceutical Science, Padang (STIFARM \\ Padang), West Sumatera, Indonesia, 25147 \\ For Correspondence: Tel. +(62) 85266031448, Email: iforafo03@ gmail.com \\ DOI: 10.47760/ijpsm.2021.v06i09.002
}

\begin{abstract}
Inflammatory diseases have affected a large proportion of the population worldwide, and inflammation is a major risk factor for several dangerous disease pathologies. The increasing incidence and impact of inflammatory diseases have prompted research into pharmacological strategies to deal with them. Chromolaena odorata is traditionally used as an antiinflammatory, antipyretic, antioxidant, analgesic, and as a wound-healing agent. Therefore, this review aimed to obtain a comprehensive review of the anti-inflammatory activity of Chromolaena odorata. This review provides evidence in the literature for the anti-inflammatory and analgesic activity of Chromolaena odorata, from 2010 to 2021. Three bibliographic databases were used as primary sources of information (PubMed, ScienceDirect, and Google Scholar). The keywords in this research were "Anti-inflammatory", "Analgesic" and "Chromolaena odorata". A total of 7 studies were included in this review according to the required criteria, 3 of which were in vitro studies and 4 in vivo studies.Pharmacological studies reported that Chromolaena odorata was proven to have anti-inflammatory activity by inhibiting NO, NF- $\kappa \beta$, p38 MAPK, IL$1 \beta$, TNF- $\alpha$, suppressed leukocyte cell migration, reduced of edema and Chromolaena odorata also was shown analgesic activity through significantly reduced stomach writhing and reduction pain sensation in rats. This review explains the potential importance of Chromolaena odorata as a natural anti-inflammatory and analgesic.
\end{abstract}

Keywords: Anti-inflammatory, Analgesic, Chromolaena odorata

\section{Introduction}

Inflammation is an essential immune response as a strategy to protect against tissue damage caused by microbes, injury and other harmful conditions [1][2]. NO (nitric oxide) is an inorganic free radical that is the main mediator of various biological responses, including inflammation [3]. Inflammatory mediators are produced through signaling pathways that are activated by inflammatory stimuli. Primary inflammatory stimuli such as microbial products and cytokines such as interleukin-1 $\beta$ (IL- $\beta$ ), interleukin-6 (IL-6) and tumor necrosis factor-alpha (TNF- $\alpha$ ) mediate inflammation through the interaction of TLRs, IL-1 receptors (IL-1R), IL-6 receptors (IL-6R), and TNF receptors (TNFR) [4]. In general, inflammation is classified into acute inflammation and chronic inflammation. Acute inflammation is a very useful process in helping to immobilize the injured area and allowing the immune system to heal the wound. On the other hand, chronic inflammation becomes a problem for wounds. Inflamed tissue stimulates immune cells from the bloodstream to amplify the inflammatory response [5][6]. Anti-inflammatory drugs such as nonsteroidal anti-inflammatory drugs (NSAIDs) are the most successful drugs used worldwide by a large number of patients, and their analgesic, anti-inflammatory, and anti-pyretic properties are widely recognized. Like many other drugs, however, Nonsteroidal Anti-Inflammatory Drugs (NSAIDs) have side effects manifested at different levels, ranging from gastrointestinal (GI), cardiovascular (CV) events, high blood pressure, renal toxicity, worsening of congestive heart failure, and heart failure. hepatotoxicity [7]-[10]. A steroid anti-inflammatory drug that tends to be used by dentists is dexamethasone with the mechanism of action of inhibiting the A2 phospholipase enzyme [11]. 


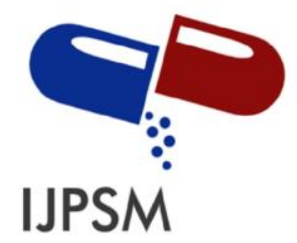
Ali Sandi Dwi Cahyo et al, Int. Journal of Pharmaceutical Sciences and Medicine (IJPSM),
Vol.6 Issue. 9, September- 2021, pg. 8-16

ISSN: 2519-9889

Impact Factor: 3.426

Medicinal plants have been a priority in public medicine for many years. About $80 \%$ of the population in Africa has utilized the therapeutic properties of medicinal plants for decades for the treatment of several diseases. Apart from the rapid development of synthetic drugs, the effectiveness and safety of medicinal plants need to be scientifically investigated [12]-[14]. Chromolaena odorata is used as a traditional medicine in West Africa and Asian countries. The main efficacy of Chromolaena odorata is known as wound treatment [15]. Several studies also reported that Chromolaena odorata has other pharmacological activities such as antioxidant [16], antibacterial [17] and cytotoxic [18]. From the results of several chemical analyzes of Chromolaena odorata, it was identified that it contains monoterpenes, sesquiterpenes, hydrocarbons, triterpenes/steroids, alkaloids and flavonoids. Leaves of Chromolaena odorata were found to be a rich source of flavonoids including quercetin, sinensetin, sakuranetin, padmatin, kaempferol and salvagenin [18],[19]. However, currently, a small fraction of Chromolaena odorata has been tested to ensure anti-inflammatory and analgesic activity. From the data obtained, there is not yet a complete literature regarding its use as an antiinflammatory and analgesic. Therefore, it is important to develop herbal knowledge that is useful in future drug discovery efforts. This paper aims to provide a current study on the anti-inflammatory and analgesic properties of Chromolaena odorata.

\section{Data Collection}

This review was conducted using different databases: Google Scholar, ScienceDirect, and Pubmed. In this update, the search terms are Anti-inflammatory, Analgesic and Chromolaena odorata collected from 20102021 as the main source of information. Only accessible online articles in Indonesian or English are reviewed, all abstracts and full-text articles were collected, examined, summarized, and conclusions were made according to which the most relevant articles were selected for screening and included in this review. The plant taxonomy has been verified from the "Plant List" database (www.theplantlist.org).

\section{Result and Discussion}

Chromolaena Odorata has anti-inflammatory and analgesic activities, according to in vitro and in vivo studies. Based on our eligibility requirements, A total of 7 studies were included in this review according to the required criteria, 3 of which were in vitro studies and 4 in vivo studies. The anti-inflammatory and analgesic properties of Chromolaena Odorata are summarized in Table I and II.

Table. 1 Anti-inflammatory activities of the Chromolaena odorata (in vitro and in vivo)

\begin{tabular}{|c|c|c|c|c|c|c|c|}
\hline $\begin{array}{c}\text { Type of } \\
\text { extract or } \\
\text { Formulation }\end{array}$ & $\begin{array}{c}\text { Plant } \\
\text { part and } \\
\text { Source } \\
\text { used for } \\
\text { studies }\end{array}$ & $\begin{array}{c}\text { Dose/ } \\
\text { Concentrati } \\
\text { on }\end{array}$ & $\begin{array}{c}\text { Experimental } \\
\text { Model }\end{array}$ & $\begin{array}{c}\text { Animal and } \\
\text { disease } \\
\text { models }\end{array}$ & $\begin{array}{c}\text { Pharmacological } \\
\text { effects (Reported } \\
\text { activity) }\end{array}$ & Country & Ref.(s) \\
\hline $\begin{array}{c}\text { Isolated } \\
\text { compounds } \\
\text { (Chalcone and } \\
\text { flavanones) }\end{array}$ & Leaves & $\begin{array}{c}\text { tnf cytokine } \\
(8-16 \mathrm{M})\end{array}$ & $\begin{array}{c}\text { LPS- } \\
\text { stimulated } \\
\text { RAW246.7 } \\
\text { macrophage } \\
\text { cell } \\
\text { (In vitro) }\end{array}$ & $\begin{array}{c}\text { RAW cells } \\
246.7\end{array}$ & $\begin{array}{c}\text { Demonstrated } \\
\text { reduced } \\
\text { production of NO } \\
\text { and inflammatory } \\
\text { mediators by } \\
\text { inhibition of the } \\
\text { NF- } \kappa \beta \text { and } p 38 \\
\text { MAPK activation } \\
\text { pathways }\end{array}$ & Thailand & [20] \\
\hline
\end{tabular}




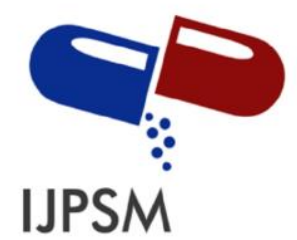

Ali Sandi Dwi Cahyo et al, Int. Journal of Pharmaceutical Sciences and Medicine (IJPSM), Vol.6 Issue. 9, September- 2021, pg. 8-16

ISSN: 2519-9889

Impact Factor: 3.426

\begin{tabular}{|c|c|c|c|c|c|c|c|}
\hline $\begin{array}{l}\text { Fatty acids } \\
\text { from } \\
\text { Chromolaena } \\
\text { odorata }\end{array}$ & $\begin{array}{c}\text { Aerial } \\
\text { part }\end{array}$ & $100 \mathrm{~L}$ & $\begin{array}{c}\text { LPS- } \\
\text { stimulated } \\
\text { RAW246.7 } \\
\text { macrophage } \\
\text { cell } \\
\text { (In vitro) }\end{array}$ & $\begin{array}{c}\text { RAW cells } \\
246.7\end{array}$ & $\begin{array}{c}\text { Fatty acids } \\
\text { isolated from } \\
\text { Chromolaena } \\
\text { odorata has an } \\
\text { anti-inflammatory } \\
\text { effect through } \\
\text { their inhibition of } \\
\text { NO and NF- } \beta \beta \\
\text { activation } \\
\end{array}$ & Vietnam & [21] \\
\hline $\begin{array}{l}\text { Ethanol } \\
\text { Extract }\end{array}$ & Leaves & $\begin{array}{c}342 \text { and } 684 \\
\mathrm{~g} / \mathrm{ml} \\
50 \mathrm{M} \text { and } \\
100 \mathrm{M} \\
\text { scutellarein } \\
\text { tetramethyl } \\
\text { ether (SCU) } \\
50 \mathrm{M} \\
\text { stigmasterol } \\
\text { and } \\
\text { isosakuranet } \\
\mathrm{n}\end{array}$ & $\begin{array}{c}\text { LPS- } \\
\text { stimulated } \\
\text { RAW246.7 } \\
\text { macrophage } \\
\text { cell } \\
\text { (In vitro) }\end{array}$ & $\begin{array}{c}\text { RAW cells } \\
246.7\end{array}$ & $\begin{array}{l}\text { Ethanol extract } \\
\text { and bioactive } \\
\text { components of } \\
\text { Chromolaena } \\
\text { odorata exert } \\
\text { anti-inflammatory } \\
\text { activity by } \\
\text { suppressing NO } \\
\text { release, } \\
\text { suppressing COX- } \\
2 \text { and iNOS } \\
\text { expression by } \\
\text { SCU. } \\
\text { Stigmasterol and } \\
\text { isosakuranetin } \\
\text { suppress PGE2 } \\
\text { release. }\end{array}$ & Thailand & [22] \\
\hline Water Extract & Leaves & $\begin{array}{c}400 \text { and } 800 \\
\mathrm{mg} / \mathrm{kg}\end{array}$ & $\begin{array}{l}\text { Foot edema } \\
\text { induced by } \\
\text { carrageenan, } \\
\text { and granuloma } \\
\text { model } \\
\text { ( in vivo) }\end{array}$ & Albino rats & $\begin{array}{c}\text { Water extract } \\
\text { activity of the } \\
\text { plant } \\
\text { Chromolaena } \\
\text { odorata showed } \\
\text { anti-inflammatory } \\
\text { activity by } \\
\text { reducing edema in } \\
\text { the paws ofalbino } \\
\text { rats }\end{array}$ & Congolese & [23] \\
\hline $\begin{array}{l}\text { Flavonoid-rich } \\
\text { fraction }\end{array}$ & Leaves & $\begin{array}{c}50 \text { and } 100 \\
\mathrm{mg} / \mathrm{kg}\end{array}$ & $\begin{array}{l}\text { AFB1-induced } \\
\text { proinflammato } \\
\text { ry cytokine } \\
\text { changes } \\
\text { (In vivo) }\end{array}$ & Rats & $\begin{array}{l}\text { Flavonoid-rich } \\
\text { fraction through a } \\
\text { significant } \\
\text { reduction of IL-1 } \beta \\
\text { and TNF- } \alpha\end{array}$ & Nigeria & [24] \\
\hline
\end{tabular}




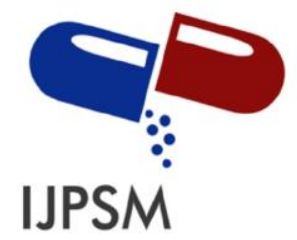

Ali Sandi Dwi Cahyo et al, Int. Journal of Pharmaceutical Sciences and Medicine (IJPSM), Vol.6 Issue. 9, September- 2021, pg. 8-16

ISSN: 2519-9889

Impact Factor: 3.426

\begin{tabular}{|c|c|c|c|c|c|c|c|}
\hline $\begin{array}{c}\text { Ethanolic } \\
\text { extract cream }\end{array}$ & Leaves & $\begin{array}{c}2.5 \% ; 5 \% \\
\text { and } 10 \%\end{array}$ & $\begin{array}{c}\text { Granuloma } \\
\text { pouch method }\end{array}$ & Mice & $\begin{array}{c}\text { The cream } \\
\text { showed anti- } \\
\text { inflammatory } \\
\text { activity by } \\
\text { reducing edema } \\
\text { and leukocyte cell } \\
\text { migration }\end{array}$ & Indonesia & [25] \\
\hline
\end{tabular}

\section{1. Anti-inflammatory activity (in vitro)}

The inflammatory response is the body's way of reacting to the beginning of the injury. This process occurs because it is regulated by leukocyte derivative products [26]. One of the most prominent leukocytes involved in the process of inflammatory development is macrophages. If there is exposure to microbes, such as bacterial lipopolysaccharides, macrophages are activated and will produce large amounts of proinflammatory mediators and cytokines, including tumor necrosis alpha (TNF- $\alpha$ ), interleukin (IL)-1, IL-6 as well as reactive oxygen and nitrogen species [27]. However, the uncontrolled or irregular release of inflammatory mediators can exacerbate injury to tissues and organs [28].

A study conducted by Dhar et al, reported the compounds chalcones 1 and 2 and flavanone 3 isolated from Chromolaena odorata showed potential anti-inflammatory effects. Chalcone 1 has been shown to reduce NO production and inflammatory mediators by inhibiting the NF- $\kappa \beta$ and p38 MAPK activation pathways. Then chalcone 2 which is a 4-methyl ether analogue of chalcone 1 was shown to be 4 times the activity of chalcone 1 . This means that the free hydroxy function at position 4 is important to maintain the high NO inhibitory activity of the chalcone. In several in vitro and in vivo pharmacological tests, chalcones from various natural plants showed various biological effects including anti-inflammatory. Chalcones are a subgroup of flavonoids, which have an aromatic enone function in the central core. Chalcones have important biological effects due to variations in their structural properties [20].

Another study conducted by Hanh et al reported that the 6 fatty acid compounds isolated from Chromolaena odorata including (S)-coriolic acid (1), (S)-coriolic acid methyl ester (2), (S)-15,16didehydrocoriolic acid (3), (S)-15,16-didehydrocoriolic acid methyl ester (4), linoleamide (5) and linolenamide (6) have the effect of inhibiting nitric oxide (NO) production and NF- $\mathrm{kB}$ activation. Fatty acids are known as one of the self-defense agents in organisms and have various biological activities including anti-inflammatory. Assay of the inhibitory effect of nitric oxide (NO) production on RAW 264.7 cells was done using lipopolysaccharide (LPS). The results showed that all compounds inhibited the production of NO with an $\mathrm{IC}_{5} 0$ value range of 5.73-47.6 M. The inhibitory effect on NF- $\kappa \beta$ activation was also examined since NF- $\kappa \beta$ has a role in regulating nitric oxide (NO) production. The results found in the NF- $\kappa \beta$ test with comparable concentrations in the nitric oxide (NO) inhibition test, that all compounds also had an inhibitory effect on NF$\kappa \beta$ activation with a range of values from 5.22 to $41.2 \mathrm{M}$. From these two tests, the compound (S)-coriolic acid methyl ester (2) showed strong activity. It should be noted that the addition of double bonds in the fatty chain decreased the inhibitory effect, in the case of (S)-coriolic acid (1) - (S)-15,16-didehydrocoriolic acid (3), (S)coriolic acid methyl ester compounds. (2) - (S)-15,16-didehydrocoriolic acid methyl ester (4) and linoleamide (5)- linolenamide (6) while methyl esterification increases the inhibitory activity, in the case of compound (S)coriolic acid (1) - ( S)-coriolic acid methyl ester (2) and (S)-15,16-didehydrocoriolic acid (3) - (S)-15,16didehydrocoriolic acid methyl ester (4) [21]. 


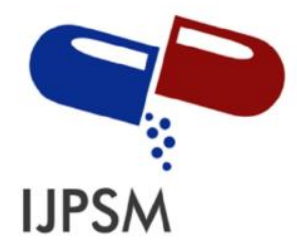

\section{Ali Sandi Dwi Cahyo et al, Int. Journal of Pharmaceutical Sciences and Medicine (IJPSM), Vol.6 Issue. 9, September- 2021, pg. 8-16}

ISSN: 2519-9889

Impact Factor: 3.426

In subsequent investigations, Pandith et al found three bioactive compounds in Chromolaena odorata. The three compounds, Scutellarein tetramethyl ether (SCU), Stigmasterol and Isosakuranetin, showed differences in expression activity COX-2 or iNOS-induced lipopolysaccharide in RAW 264.7 cells. Although there are no studies that report anti-inflammatory activity on scutellarein tetramethyl ether (SCU) compounds, the results of this investigation show that scutellarein tetramethyl ether compounds have strong inflammatory activity. Many reports have shown that phytochemicals affect anti-inflammatory activity through inhibition of p65 translocation from the cytoplasm to the nucleus, as demonstrated by the compound scutellarein tetramethyl ether. On the other hand, isosacuranethin compounds reported to have anti-inflammatory activity in this investigation could not find suppression of COX-2 and iNOS, indicating that isosacuranethin compounds have anti-inflammatory activities that are independent of COX-2 and iNOS. The results showed that Scutellarein tetramethyl ether (SCU) and stigmasterol were the main bioactive compounds that exhibited anti-inflammatory activity of Siam Weed Extract (SWE) [22].

\section{2. Anti-inflammatory activity (in vivo)}

To investigate for potential action against pro-inflammatory mediators, researchers employed the carrageenan-induced edema experiment. This model has two phase early phase that begins 6 hours after carrageenan injection and ends 72 hours later, and a later phase that begins 6 hours after carrageenan injection and ends 72 hours later. Between 48 and 72 hours, inflammation reaches its peak [29]. In the early stages of this experiment, histamine, serotonin, and increased prostaglandin synthesis were identified (between $1 \mathrm{~h}$ and 2 $\mathrm{h}$ after injection). Direct prostaglandins released by damaged tissue, as well as bradykinin, leukotrienes, polymorphonuclear cells, and macrophage-produced prostaglandins, trigger the later stage of edema [30], [31]. In addition, The subcutaneous air pouch is an in vivo model that can be used to study the components of acute and chronic inflammation, the resolution of the inflammatory response, the oxidative stress response, and potential therapeutic targets for treating inflammation. Injection of irritants into an air pouch in rats or mice induces an inflammatory response that can be quantified by the volume of exudate produced, the infiltration of cells, and the release of inflammatory mediators. The model presented in this unit has been extensively used to identify potential anti-inflammatory drugs [32]. Chromolaena odorata has been demonstrated to have antiinflammatory properties by lowering edema in various previous investigations, including the one below.

Itou et al. reported an investigation of the anti-inflammatory effect on leaves of Chromolaena odorata. Anti-inflammatory was evaluated using carrageenan and formaldehyde to induce acute inflammation and cotton pallets to induce chronic inflammation. One hour later, Chromolaena odorata extract was injected with different doses (400 and $800 \mathrm{mg} / \mathrm{kg}$ ). Chromolaena odorata extract ( 400 and $800 \mathrm{mg} / \mathrm{kg}$ ) inhibited the development of edema caused by carrageenan with a maximum inhibition of four hours after administration of carrageenan compared to the control group. In fact, the extract at the same dose also combats formaldehydeinduced acute inflammation and granulomas caused by cotton pallets. These results prove that Chromolaena odorata extract (400-800 mg/kg) has an anti-inflammatory effect [23].

Furthermore, Amid et al evaluated the anti-inflammatory activity of the flavonoid-rich fraction of chromolaena odorata on the reduction of proinflammatory cytokines and $\mathrm{NO}$ in wistar rats. Wistar rats were induced by aflatoxin B1 in the gastric mucosa, then given FRFC (Flavonoid-Rich Fraction) in 2 doses (50 and $100 \mathrm{mg} / \mathrm{kg}$ ). It was proven that FRFC was able to significantly reduce IL- $1 \beta$ and TNF-a at a dose of $100 \mathrm{mg} / \mathrm{kg}$ when compared to a dose of $50 \mathrm{mg} / \mathrm{kg}$. In fact, FRFC was also able to significantly reduce NO levels when the FRFC dose was increased from 50 to $100 \mathrm{mg} / \mathrm{kg}$ [24].

Another study conducted by ifora $e t$ al. reported that the ethanolic extract cream of Chromolaena odorata (L) R.M. King \& H. Rob. leaves at a concentration of 2.5\%; $5 \%$ and $10 \%$ demonstrated its ability to suppress inflammation. This study also explains that increasing the dosage of the preparation can suppressed leukocyte cell migration, and reduced oedema. The number of leukocytes from the blood of mice after administration of the cream of Chromolaena odorata extract showed an increase in the number of neutrophils, 


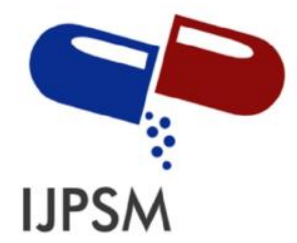

Ali Sandi Dwi Cahyo et al, Int. Journal of Pharmaceutical Sciences and Medicine (IJPSM), Vol.6 Issue. 9, September- 2021, pg. 8-16

ISSN: 2519-9889

Impact Factor: 3.426

monocytes, and lymphocytes. While the eosinophil cells was reduced. The decrease in eosinophil cells in the blood of male white mice was probably because these cells have migrated to the area of inflammation [25].

\section{B. Analgesic activity (in vivo)}

Table 2 Analgesic activites from the Chromolaena odorata (in vivo study)

\begin{tabular}{|c|c|c|c|c|c|c|c|}
\hline $\begin{array}{c}\text { Type of } \\
\text { extract or } \\
\text { Formulation }\end{array}$ & $\begin{array}{c}\text { Plant } \\
\text { part and } \\
\text { Source } \\
\text { used for } \\
\text { studies }\end{array}$ & $\begin{array}{c}\text { Dose/ } \\
\text { Concentration }\end{array}$ & $\begin{array}{c}\text { Experimental } \\
\text { Model }\end{array}$ & $\begin{array}{l}\text { Animal } \\
\text { and } \\
\text { disease } \\
\text { models }\end{array}$ & $\begin{array}{l}\text { Pharmacologi } \\
\text { cal effects } \\
\text { (Reported } \\
\text { activity) }\end{array}$ & Country & $\begin{array}{l}\text { Reference } \\
\text { (s) }\end{array}$ \\
\hline $\begin{array}{l}\text { Aqueous } \\
\text { extract }\end{array}$ & Leaves & $\begin{array}{c}400 \text { and } 800 \\
\mathrm{mg} / \mathrm{kg}\end{array}$ & $\begin{array}{c}\text { 1. Pain } \\
\text { induced by } \\
\text { acetic acid } \\
\text { 2. Pain } \\
\text { induced by } \\
\text { formaldehyde }\end{array}$ & Albino rat & $\begin{array}{c}\text { Extract } \\
\text { provided anti- } \\
\text { inflammatory } \\
\text { and analgesic } \\
\text { effects after } \\
\text { being induced } \\
\text { with several } \\
\text { compounds. }\end{array}$ & Congo & [23] \\
\hline $\begin{array}{l}\text { Ethanol } \\
\text { fraction }\end{array}$ & Leaves & $\begin{array}{l}100,200 \text { and } \\
400 \mathrm{mg} / \mathrm{kg}\end{array}$ & $\begin{array}{l}\text { 1. Tail flick } \\
\text { test in rats } \\
2 . \text { Stomach } \\
\text { writhing test } \\
\text { induced by } \\
\text { acetic acid }\end{array}$ & Wistar rat & $\begin{array}{l}\text { Ethanol } \\
\text { fraction exerts } \\
\text { anti- } \\
\text { inflammatory } \\
\text { and analgesic } \\
\text { effect through } \\
\text { response } \\
\text { effect flick tail } \\
\text { and stomach } \\
\text { writhing effect } \\
\text { at the tested } \\
\text { dose }\end{array}$ & Nigeria & [33] \\
\hline
\end{tabular}

A study conducted by Itou, et al reported tant the test results of Chromolaena odorata extract with acetic acid inducer showed a significant decrease in stomach writhing in albino rats compared to the control group, namely paracetamol with a difference of $24.15 \%$ inhibition at a dose of $400 \mathrm{mg} / \mathrm{kg}$ and $27.56 \%$ at a dose of $800 \mathrm{mg} / \mathrm{kg}$. Then, in testing the analgesic effect of Chromolaena odorata extract using an analgesymeter, it significantly increased the reaction time of animals to pain $(p>0.001)$ compared to the control group, namely paracetamol. This also proves that the analgesic effect obtained at a dose of $800 \mathrm{mg} / \mathrm{kg}$ is stronger than the analgesic effect produced at a dose of $400 \mathrm{mg} / \mathrm{kg}$ [23].

Meanwhile, at the central level, an evaluation of the analgesic effect in mice induced by formaldehyde compounds was also carried out. After testing, the extracts of Chromolaena odorata and tramadol were proven to significantly $(\mathrm{p}<0.001)$ reduce the frequency of licking and biting the test animal's paws compared to the 


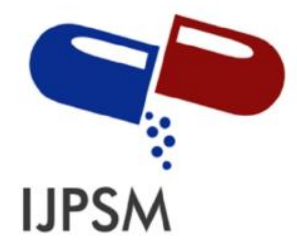
Ali Sandi Dwi Cahyo et al, Int. Journal of Pharmaceutical Sciences and Medicine (IJPSM),
Vol.6 Issue. 9, September- 2021, pg. 8-16

ISSN: 2519-9889

Impact Factor: 3.426

control group. Chromolaena odorata extract at a dose of $800 \mathrm{mg} / \mathrm{kg}$ and tramadol were better at inhibiting inflammatory and neurogenic pain in animals. These results indicate that the extract of Chromolaena odorata $(400-800 \mathrm{mg} / \mathrm{kg})$ also has an analgesic effect. A phytochemical study of the extract of Chromolaena odorata revealed that the presence of saponins, alkaloids and flavonoids could explain the anti-inflammatory and analgesic effects [23].

Analgesic activity was also evaluated by Onoja et al Analgesic activity test was carried out using the stomach writhing test and tail-flick response in rats induced by acetic acid. In the test of the response of the rat tail-flick, the extract was given at different doses $(100,200$ and $400 \mathrm{mg} / \mathrm{kg}$ ) and produced a significant reduction in pain sensation, namely the reaction time of pain of $51.33 \%, 33.33 \%$ and $45.33 \%$, where at a dose of $51.33 \%, 33.33 \%$ and $45.33 \% 100 \mathrm{mg} / \mathrm{kg}$ pain reaction time of the extract $(51.33 \%)$ was comparable to the negative control (57.33\%). Whereas in the stomach writhing test, the extract was given in 2 doses (200 and 400 $\mathrm{mg} / \mathrm{kg}$ ), and significantly reduced stomach writhing in rats by the percentage of $63.64 \%, 13.13 \%$ and $27.27 \%$ when compared with negative controls [33].

\section{Conclusion and Future Prospects}

Natural products provide important clues for the development of drugs, including anti-inflammatory and analgesic agents. This review described the importance of Chromolaena odorata as a potent natural antiinflammatory and analgesic. A collection of pharmacological studies reported the potential of Chromolaena odorata for the treatment of diseases associated with inflammatory stimuli. This study also confirmed the in vitro and in vivo anti-inflammatory and analgesic effects of Chromolaena odorata, Chromolaena odorata plant exhibits anti-inflammatory activity with several mechanisms including reducing NO production and inflammatory mediators by inhibiting NF-KB and p38 MAPK activation pathways, as well as significantly reducing the production of IL- $1 \beta$ and TNF- $\alpha$, suppressed leukocyte cell migration, reduced of edema and Chromolaena odorata providing analgesic activity through significantly reduced stomach writhing and reduction pain sensation in rats. The anti-inflammatory and analgesic effects of Chromolaena odorata depend on the dose and type of formulation to be administered. However, further research needs to be done to understand the metabolic processes and the role of metabolites as anti-inflammatory and analgesic in the body as a start for the development of new anti-inflammatory and analgesic drugs in the future.

\section{Acknowledgements}

The authors are grateful to all colleagues at The Departement of Pharmacology and Clinical Pharmacy, School of Pharmaceutical Science Padang (STIFARM Padang), for helpful discussions.

\section{Conflict of Interest}

The authors declare that they have no conflicts of interest.

\section{References}

[1]. A. U. Ahmed, “An overview of inflammation: Mechanism and consequences," Front. Biol. China, vol. 6, no. 4, pp. 274-281, 2011.

[2]. R. Medzhitov, “Overview Essay Inflammation 2010 : New Adventures of an Old Flame,” pp. 771776, 2010.

[3]. B. H. Maskrey, I. L. Megson, P. D. Whitfield, and A. G. Rossi, "Mechanisms of resolution of inflammation: A focus on cardiovascular disease," Arterioscler. Thromb. Vasc. Biol., vol. 31, no. 5, pp. 1001-1006, 2011.

[4]. L. Chen et al., "Oncotarget 7204 www.impactjournals.com/oncotarget Inflammatory responses and 


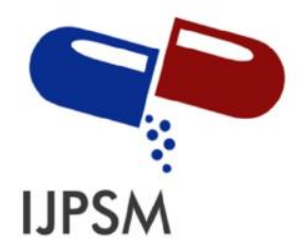

Ali Sandi Dwi Cahyo et al, Int. Journal of Pharmaceutical Sciences and Medicine (IJPSM), Vol.6 Issue. 9, September- 2021, pg. 8-16

ISSN: 2519-9889

Impact Factor: 3.426

inflammation-associated diseases in organs," Oncotarget, vol. 9, no. 6, pp. 7204-7218, 2018.

[5]. P. Aghasafari, U. George, and R. Pidaparti, "A review of inflammatory mechanism in airway diseases," Inflamm. Res., vol. 68, no. 1, pp. 59-74, 2019.

[6]. J. N. Fullerton and D. W. Gilroy, "Resolution of inflammation: a new therapeutic frontier," Nat. Publ. Gr., vol. 15, no. 8, pp. 551-567, 2016.

[7]. A. Al-kaf, Nonsteroidal Anti-Inflammatory Edited by Ali Gamal Al-kaf, no. March. 2018.

[8]. C. Sostres, C. J. Gargallo, and A. Lanas, "Nonsteroidal anti-inflammatory drugs and upper and lower gastrointestinal mucosal damage," Arthritis Res. Ther., vol. 15, no. SUPPL 3, pp. 1-8, 2013.

[9]. C. Sostres, C. J. Gargallo, M. T. Arroyo, and A. Lanas, "Adverse effects of non-steroidal antiinflammatory drugs (NSAIDs, aspirin and coxibs) on upper gastrointestinal tract," Best Pract. Res. Clin. Gastroenterol., vol. 24, no. 2, pp. 121-132, 2010.

[10].S. Harirforoosh, W. Asghar, and F. Jamali, "Adverse effects of nonsteroidal antiinflammatory drugs: An update of gastrointestinal, cardiovascular and renal complications," J. Pharm. Pharm. Sci., vol. 16, no. 5, pp. 821-847, 2013.

[11].M. F. S. Peres, F. V. Ribeiro, K. G. S. Ruiz, F. H. Nociti-Jr, E. A. Sallum, and M. Z. Casati, "Steroidal and non-steroidal cyclooxygenase-2 inhibitor anti-inflammatory drugs as pre-emptive medication in patients undergoing periodontal surgery," Braz. Dent. J., vol. 23, no. 6, pp. 621-628, 2012.

[12].E. E. Elgorashi and L. J. McGaw, "African plants with in vitro anti-inflammatory activities: A review," South African J. Bot., vol. 126, pp. 142-169, 2019.

[13].Y. Y. Siew, S. Zareisedehizadeh, W. G. Seetoh, S. Y. Neo, C. H. Tan, and H. L. Koh, "Ethnobotanical survey of usage of fresh medicinal plants in Singapore," J. Ethnopharmacol., vol. 155, no. 3, pp. 1450-1466, 2014.

[14].N. Gupta, U. K. Jain, A. Jain, G. Lovanshi, N. Mathan, and V. Tiwari, "Review of Some Important Medicinal Plants Possesses Anti-Inflammatory Activity," Res. J. Pharm. Tech, vol. 4, no. 10, pp. $1506-1512,2011$.

[15].A. G. Omokhua, L. J. McGaw, J. F. Finnie, and J. Van Staden, "Chromolaena odorata (L.) R.M. King $\&$ H. Rob. (Asteraceae) in sub-Saharan Africa: A synthesis and review of its medicinal potential," $J$. Ethnopharmacol., vol. 183, pp. 112-122, 2016.

[16].K. Srinivasa Rao, P. K. Chaudhury, and A. Pradhan, "Evaluation of anti-oxidant activities and total phenolic content of Chromolaena odorata," Food Chem. Toxicol., vol. 48, no. 2, pp. 729-732, 2010.

[17].M. Atindehou et al., "Isolation and Identification of Two Antibacterial Agents from \&lt;i\&gt;Chromolaena odorata\&lt;/i\&gt; L. Active against Four Diarrheal Strains," Adv. Microbiol., vol. 03, no. 01, pp. 115-121, 2013.

[18].V. Prabhu and S. Ravi, "Isolation of a novel triterpene from the essential oil of fresh leaves of Chromolaena odorata and its in-vitro cytotoxic activity against HepG2 cancer cell line," J. Appl. Pharm. Sci., vol. 2, no. 9, pp. 132-136, 2012.

[19].K. Vijayaraghavan, J. Rajkumar, S. N. A. Bukhari, B. Al-Sayed, and M. A. Seyed, "Chromolaena odorata: A neglected weed with a wide spectrum of pharmacological activities (Review)," Mol. Med. Rep., vol. 15, no. 3, pp. 1007-1016, 2017.

[20].R. Dhar, R. Kimseng, R. Chokchaisiri, T. Utaipan, A. Suksamrarn, and W. Chunglok, "from Chromolaena odorata possesses anti- inflammatory effects via inhibition of NF- $\kappa$ B and p38 MAPK in lipopolysaccharide-activated RAW," Immunopharmacol. Immunotoxicol., vol. 0, no. 0, pp. 1-9, 2017.

[21].H. Hanh, T. Thi, D. Thi, T. Hang, C. Van Minh, and N. T. Dat, "Anti-inflammatory effects of fatty acids isolated from Chromolaena odorata," Asian Pac. J. Trop. Med., vol. 4, no. 10, pp. 760-763, 2011.

[22].H. Pandith, X. Zhang, and S. Thongpraditchote, "Effect of Siam weed extract and its bioactive component scutellarein tetramethyl ether on anti-in fl ammatory activity through NF- $\kappa$ B pathway," $J$. 


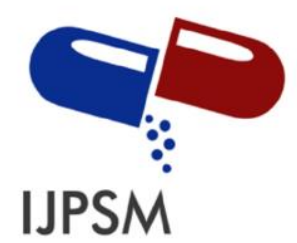

Ali Sandi Dwi Cahyo et al, Int. Journal of Pharmaceutical Sciences and Medicine (IJPSM), Vol.6 Issue. 9, September- 2021, pg. 8-16

ISSN: 2519-9889

Impact Factor: 3.426

Ethnopharmacol., vol. 147, no. 2, pp. 434-441, 2013, doi: 10.1016/j.jep.2013.03.033.

[23].R. D. G. Itou Elion, et al., "Anti-inflammatory and analgesic effects of leaves of Chromolaena odorata

L. (King and Robinson)," African J. Pharm. Pharmacol., vol. 11, no. 17, pp. 217-223, 2017.

[24].A. S. Amid, O. A. Makinde, and F. J. Akinrinmade, "Effects of Melatonin and Flavonoid-Rich Fractions Cytokines and Nitric Oxide Induced by Aflatoxin B1," vol. 00, no. 00, pp. 1-6, 2020.

[25].Ifora, H. Arifin, and R. Silvia, "Efek Antiinflamasi Krim Ekstrak Etanol Daun Kirinyuh ( Chromolaena odorata (L) R.M. King \& H. Rob ) Secara Topikal dan Penentuan Jumlah Sel Leukosit Pada Mencit Putih Jantan,” J. Farm. Higea, vol. 9, no. 1, pp. 68-76, 2017.

[26].Carl Nathan, "Points of control in inflammation," Nature, vol. 420, no. 19/26, pp. 846-852, 2002.

[27].T. J. Koh and L. A. DiPietro, "Inflammation and wound healing: the role of the macrophage.," Expert Rev. Mol. Med., vol. 13, no. July 2011, 2011.

[28].D. L. Laskin, V. R. Sunil, C. R. Gardner, and J. D. Laskin, "Macrophages and Tissue Injury: Agents of Defense or Destruction," 2011, doi: 10.1146/annurev.pharmtox.010909.105812.

[29].P. Annamalai and E. B. Thangam, "Local and Systemic Profiles of Inflammatory Cytokines in Carrageenan-induced Paw Inflammation in Rats," Immunol. Invest., vol. 46, no. 3, pp. 274-283, 2017.

[30].E. Vazquez et al., "Systemic changes following carrageenan-induced paw inflammation in rats," Inflamm. Res., vol. 64, no. 5, pp. 333-342, 2015.

[31].A. C. Zarpelon et al., "IL-33/ST2 signalling contributes to carrageenin-induced innate inflammation and inflammatory pain: Role of cytokines, endothelin-1 and prostaglandin E 2," Br. J. Pharmacol., vol. 169, no. 1, pp. 90-101, 2013.

[32].D. B. Duarte, M. R. Vasko, and J. C. Fehrenbacher, "Models of Inflammation: Carrageenan Air Pouch," Curr. Protoc. Pharmacol., no. March, pp. 1-9, 2016.

[33].S. Onoja, E. Nweze, M. Ezeja, Y. Omeh, and C. Obi, "Evaluation of the Antioxidant and Analgesic Activities of Hydromethanolic Extract of Chromolaena odorata Leaf," Br. J. Pharm. Res., vol. 10, no. 5, pp. 1-7, 2016. 